DuthIE, E. S. (1954). J. gen. Microbiol. 10, 437-444.

\title{
The Production of Free Staphylococcal Coagulase
}

\author{
By E. S. DUTHIE \\ Royal South Hants Hospital, Southampton
}

SUMMARY: Free staphylococcal coagulase is formed early in the lag phase and is released continuously, mainly at the first division in heavily seeded cultures. With most strains the presence of serum albumin in the medium greatly enhances the production of both free and bound coagulase (Duthie, 1954). The albumin factor is relatively heat stable, but is easily destroyed by crystalline trypsin.

Duthie (1954) has shown that there are at least two forms of staphylococcal coagulase, one bound and one free, which differ in their mode of action, antigenic pattern and occurrence. Previous studies on coagulase production were concerned only with free coagulase which is liberated into the medium and is recognized by the formation of a clot when added to a suitable plasma. Walston (1935), Walker, Derow \& Schaffer (1948) and Tager \& Hales (1947) produced free coagulase in liquid media such as digest broth, when the bacteria were grown in static culture at $37^{\circ}$ for periods up to a week. Lominski (1944) showed that coagulase production under these conditions was enhanced by the addition of human plasma to the medium. Davies (1951) studied the effect of serum on the production of coagulase when large inocula were used. He stated that coagulase was produced only during the latter part of the lag phase, and that the addition of rabbit serum at this time to a broth initially without serum produced a rapid release of coagulase into the medium. In studies by Duthie \& Lorenz (1952), who used only one strain ('Newman') of staphylococcus, it was repeatedly shown that addition of plasma or serum to the medium did not increase the yield of free coagulase. On repeating the experiments of Davies with other staphylococcal strains it was found that most of them gave increased yields of coagulase in the presence of serum. However, of the four strains used to produce coagulase of the four different antigenic types (Duthie, 1952), three (including strain 'Newman') did not show enhancement and consequently were atypical. So far it has not been possible to produce the coagulase of the fourth one, type $\mathrm{D}$, in any quantity without the addition of serum or albumin to the medium. In consequence it has not been possible to obtain it in a form suitable for a vaccine. The studies now reported were incidental to solving this problem, and though this has not been achieved, they have revealed some new factors concerning coagulase production.

\section{METHODS}

Coagulase production. Stock cultures of staphylococci for seeding were obtained by growing strains in digest broth in flasks supported on a slightly inclined rotating gramophone turntable. The total count was $4-10 \times 10^{9}$ organisms $/ \mathrm{ml}$. at $18 \mathrm{hr}$. and cultures could be stored for a week at $4^{\circ}$ without alteration in their behaviour when used for seeding. Unless otherwise stated, 
stock cultures were diluted to $10 \%(\mathrm{v} / \mathrm{v})$ in warm broth and were rotated in conical flasks at $37^{\circ}$.

Assay of free coagulase. Measured volumes ( 0.1 or $0.2 \mathrm{ml}$.) of dilution of culture supernatant in broth were added to $0.2 \mathrm{ml}$. of a $0.4 \%(\mathrm{w} / \mathrm{v})$ solution of bovine fibrinogen containing also $0.5 \%(\mathrm{v} / \mathrm{v})$ rabbit plasma in tubes $5.0 \times 0.8 \mathrm{~cm}$.; the fibrinogen solution was warmed before the addition of coagulase. Each tube was held against a black background in a warm illuminated box and tapped at intervals until a definite clot appeared; this time was measured accurately. For times up to about $3 \mathrm{~min}$. the reciprocal of the coagulase concentration plotted against the clotting time gave a straight line, the relation between coagulase and clotting time being similar to that found in the case of thrombin + fibrinogen mixtures (Biggs \& Macfarlane, 1953). A series of these lines for different preparations of coagulase showed that they intersected the time axis at about $15 \mathrm{sec}$., which corresponded to the time lag when a large amount of coagulase was used in the test. For periods longer than $3 \mathrm{~min}$. the lines tended to curve, possibly because the end-points were difficult to read accurately. The straight lines extrapolated were then used as an approximate measure of coagulase concentrations for these longer clotting times. A dried preparation of coagulase containing 6000 minimal clotting doses (M.C.D.)/mg. was used as a standard.

Coagulase activator. This was measured in a similar way to free coagulase: $0.1 \mathrm{ml}$. of coagulase $3000 \mathrm{M} . \mathrm{C} . \mathrm{D} . / \mathrm{ml}$. was added to a mixture containing $0 \cdot 1 \mathrm{ml}$. activator solution to be tested and $0.2 \mathrm{ml} .0 .4 \%(\mathrm{w} / \mathrm{v})$ bovine fibrinogen (Armour's fraction 1). By using a known activator solution as reference, the clotting times plotted against the reciprocal of the activator dilution again gave a straight line.

Bacterial counts. Fully-grown shaken cultures were easily counted in redcell counting chambers since the cells rarely formed groups of more than two or three. During the logarithmic phase counting soon became inaccurate, and was not used when the staphylococcal clumps became large.

\section{EXPERIMENTAL}

That the addition of serum to the medium does not always enhance coagulase production is indicated in Table 1. Strains 2, 59 and 22 (corresponding to the A, B and C strains described earlier (Duthie, 1952)) were unaffected, but

Table 1. Effect of addition of rabbit serum to culture medium on the production of free coagulase by different strains of staphylococci

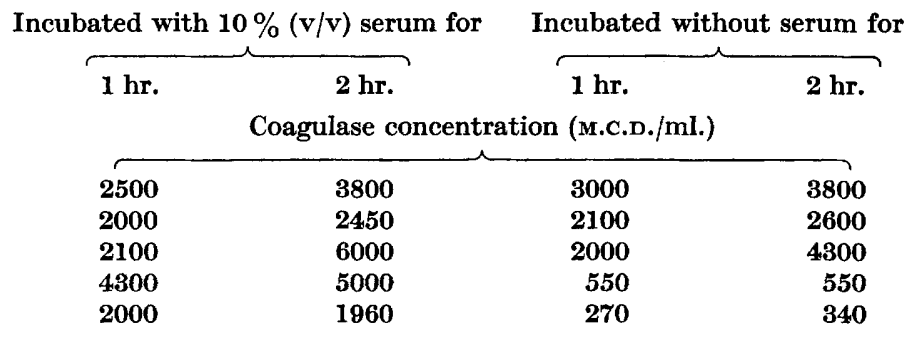


strains 176 and $\mathbf{3 4 6}$ were more typical, in that the addition of serum greatly increased the final yield. A comparison (Table 2) of the sera of a number of animals showed enhancement of production in the case of all those examined. Apart from mouse plasma, which had a smaller enhancing effect, there was no difference between the plasmas and sera of the other animals. Armour's bovine albumin (fraction $V$ ) was equal if not superior to any of the sera tested.

Table 2. Effect of addition of serum $(10 \% v / v)$ of different animals to culture medium on production of coagulase by staphylococcal strain 346

Period of incubation of culture

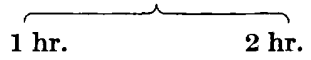

Coagulase concentration

\begin{tabular}{lrr}
\multicolumn{1}{c}{ Origin of serum } & \multicolumn{2}{c}{$(\overbrace{20}$} \\
Mouse & $\mathbf{1 3 2 0}$ & 1320 \\
Guinea-pig & 2000 & 2000 \\
Rabbit & 2000 & 3000 \\
Sheep & 1740 & 1740 \\
Cow & 2000 & 2000 \\
Horse & 1800 & 1800 \\
Pig & 3000 & 3000 \\
Man & 2400 & 2400 \\
Bovine albumin $0.5 \%(w / v)$ & 3500 & 2600 \\
Nil & 270 & 270
\end{tabular}

Serum fractionation

The results obtained with different fractions of plasma or serum after treatment with ammonium sulphate (Table 3) show that the enhancing effect of plasma or serum on coagulase production was due to the albumin fraction: this was confirmed with the plasmas of several species. Table 4 shows that the addition of increasing amounts of purified bovine albumin (Armour's fraction V) to the medium was accompanied by an increase in the amount of coagulase formed. Since this source of albumin was readily accessible, sterile, and uniform in its results, it was used in subsequent work at a concentration of $0 \cdot 3 \%(w / v)$ albumin.

Table 3. Effect of different fractions of human plasma (ammonium sulphate precipitation) added to the culture medium on the production of coagulase by staphylococcus strain 346

Final concentration of each fraction equivalent to that present when $10 \%(\mathrm{v} / \mathrm{v})$ plasma was added.

Material added

Human plasma $10 \%$ (v/v)

Dialysed human plasma $10 \%(\mathrm{v} / \mathrm{v})$

Human globulin

Human albumin

Bovine albumin 0.3\% (w/v)
Period of incubation

$1 \mathrm{hr}$. $2 \mathrm{hr}$.

Coagulase concentration

$$
\text { (M.C.D./ml.) }
$$

$\begin{array}{rr}1740 & 3500 \\ 2400 & 2400 \\ 500 & 500 \\ 3500 & 2400 \\ 2400 & 3500\end{array}$


Table 4. Effect of adding different concentrations of bovine albumin (fraction $V$ ) to the culture medium on the formation of coagulase by staphylococcus strain 346

Coagulase concentration was measured after incubation at $37^{\circ}$ for $2 \mathrm{hr}$.

$\begin{array}{cc}\begin{array}{c}\text { Albumin } \\ (\%, w / v)\end{array} & \begin{array}{c}\text { Coagulase } \\ \text { concentration } \\ \text { (M.c.D./ml.) }\end{array} \\ 1 \cdot 0 & 3000 \\ 0.5 & 2600 \\ 0.3 & 1600 \\ 0 \cdot 15 & 1540 \\ 0.08 & 1400 \\ 0.04 & 1260\end{array}$

Heat stability and nature of the albumin fraction

When held at $60^{\circ}$ for $20 \mathrm{~min}$. the albumin fraction was most stable at $\mathrm{pH} 2 \cdot 0$ or less. There was an apparent loss at $\mathrm{pH} 4 \cdot 6$, but this was eliminated when the somewhat cloudy albumin was brought to $\mathrm{pH} 2$ and then rapidly made neutral. There was a marked loss above $\mathrm{pH} 8.5$ which was not reversible.

When $3 \%(\mathrm{w} / \mathrm{v})$ bovine albumin in $0.1 \mathrm{~N}-\mathrm{HCl}$ was held for $20 \mathrm{~min}$. at temperatures above $60^{\circ}$, there was no loss at $70^{\circ}$, a $50 \%$ loss at $90^{\circ}$, and a $75 \%$ loss at $100^{\circ}$ in the amount of coagulase subsequently formed. Davies (1951) showed that the coagulase enhancing factor in serum was destroyed by pepsin. Table 5 shows that it was also readily damaged by small amounts of crystalline trypsin (flask 2) though not when soya-bean inhibitor was present in the original incubation mixture (flask 3). The later addition of the inhibitor to flask 4 was a safeguard against possible destruction of the coagulase by trypsin, but as will be seen from Table 5, was not necessary in this case. Gelatin, egg albumin, protamine and casein were inactive; egg yolk was less effective than most sera.

Table 5. Destruction by crystalline trypsin of the factor in bovine albumin which promotes coagulase production

One volume of each of the following additional mixtures was added to a flask containing 4 vol. of seeded broth. The constituents of the mixtures were in the following concentrations: albumin $1.5 \%(w / v)$, trypsin $10^{-5}(w / v)$, soya-bean inhibitor $10^{-5}(w / v)$.

\begin{tabular}{|c|c|c|c|}
\hline \multirow[b]{4}{*}{ Flask } & \multirow[b]{4}{*}{ Mixture } & \multicolumn{2}{|c|}{ Period of incubation } \\
\hline & & $1 \mathrm{hr}$. & $2 \mathrm{hr}$. \\
\hline & & \multirow{2}{*}{\multicolumn{2}{|c|}{$\begin{array}{c}\text { Coagulase concentration } \\
\text { (M.C.D. } / \mathrm{ml} \text {. })\end{array}$}} \\
\hline & & & $\longrightarrow$ \\
\hline $\mathbf{1}$ & Albumin, 2 hr., $37^{\circ}, \mathrm{pH} 8$ & 2000 & 2400 \\
\hline 2 & Albumin + trypsin, $2 \mathrm{hr} ., 37^{\circ}, \mathrm{pH} 8$ & 940 & 880 \\
\hline $\mathbf{3}$ & $\begin{array}{l}\text { Albumin + soya-bean inhibitor + trypsin, } \\
\mathbf{2} \mathrm{hr} ., 37^{\circ}, \mathrm{pH} 8\end{array}$ & 2350 & 3000 \\
\hline 4 & $\begin{array}{l}\text { Albumin }+ \text { trypsin, } 2 \mathrm{hr} ., 37^{\circ}, \mathrm{pH} 8 \text {, } \\
\text { then soya-bean inhibitor added }\end{array}$ & 600 & 570 \\
\hline
\end{tabular}




\section{Effect of varying the time of albumin addition and inoculum size}

Although Davies(1951) stated that coagulase is produced during the latter part of the lag phase, this was not confirmed by his tables nor by the values shown in Table 6. In this experiment four flasks containing a broth +albumin medium were inoculated with falling numbers of staphylococci while a fifth heavily seeded flask contained no albumin. Practically all the coagulase of the most heavily seeded flask containing albumin was formed by the first division. With smaller inocula coagulase production was continuous through the logarithmic phase and in the most lightly seeded flask was equal at the fifth hour (not shown) to that in any of the first three flasks.

Table 6. Effect of inoculum size on the production of coagulase by staphylococcus strain 346 in medium containing $0 \cdot 3 \%$ (w/v) albumin

\begin{tabular}{|c|c|c|c|}
\hline $\begin{array}{c}\text { Incubation } \\
(\mathrm{hr} .)\end{array}$ & $\begin{array}{c}\text { Flask } \\
\text { no. }\end{array}$ & $\begin{array}{c}\text { Count } \\
\left(10^{6} / \mathrm{ml} .\right)\end{array}$ & $\begin{array}{l}\text { Coagulase } \\
\text { production } \\
\text { (M.c.D./ml.) }\end{array}$ \\
\hline 0 & $\begin{array}{l}1 \\
2 \\
3 \\
4 \\
5^{*}\end{array}$ & $\begin{array}{r}166 \cdot 4 \\
41 \cdot 6 \\
10 \cdot 4 \\
2 \cdot 7 \\
166 \cdot 4\end{array}$ & $\begin{array}{r}80 \\
20 \\
5 \\
-\end{array}$ \\
\hline 1 & $\begin{array}{l}1 \\
2 \\
3 \\
4 \\
5^{*}\end{array}$ & $\begin{array}{c}302 \\
55 \\
10 \\
2 \cdot 7 \\
302\end{array}$ & $\begin{array}{r}2700 \\
790 \\
135 \\
50 \\
550\end{array}$ \\
\hline 2 & $\begin{array}{l}1 \\
2 \\
8 \\
4 \\
5^{*}\end{array}$ & $\begin{array}{c}640 \\
120 \\
19 \\
3 \cdot 0 \\
640\end{array}$ & $\begin{array}{r}3700 \\
2700 \\
420 \\
50 \\
900\end{array}$ \\
\hline 3 & $\begin{array}{l}1 \\
2 \\
3 \\
4 \\
5^{*}\end{array}$ & $\begin{array}{r}1200 \\
444 \\
- \\
5 \cdot 0 \\
1200\end{array}$ & $\begin{array}{r}3700 \\
3700 \\
1600 \\
110 \\
900\end{array}$ \\
\hline 4 & $\begin{array}{l}1 \\
2 \\
3 \\
4 \\
5^{*}\end{array}$ & $\begin{array}{r}3000 \\
614 \\
- \\
10 \\
3000\end{array}$ & $\begin{array}{l}3700 \\
3700 \\
3000 \\
1240 \\
1240\end{array}$ \\
\hline
\end{tabular}

For albumin to exert its optimal effect it was essential that it should be added early in the growth cycle; its effect decreased with the number of divisions which had occurred before it was added (Table 7). Thus additions made after $20 \mathrm{~min}$. to the heavily inoculated flasks or after $2 \mathrm{hr}$. to the more lightly inoculated ones, became progressively less effective with increase of time and hence of cell multiplication. As before, coagulase production was not confined to the lag phase. 
Table 7. Effect of adding bovine albumin $0.5 \%(w / v)$ to cultures of staphylococcus strain 346 at different times after seeding

\begin{tabular}{|c|c|c|c|}
\hline \multirow[b]{2}{*}{$\begin{array}{l}\text { Bovine albumin } \\
\text { added at } \\
\text { (min.) after } \\
\text { inoculation }\end{array}$} & \multirow[b]{2}{*}{$\underset{\left(10^{6} / \mathrm{ml} .\right)}{\text { Cells }}$} & \multicolumn{2}{|c|}{ Period of incubation } \\
\hline & & \multicolumn{2}{|c|}{$\begin{array}{l}\text { Coagulase formed } \\
\text { (M.C.D./ml.) }\end{array}$} \\
\hline 10 & $157 \cdot 5$ & 1230 & 4000 \\
\hline 20 & 157 & 1170 & 4000 \\
\hline 40 & 237 & 900 & 3750 \\
\hline 60 & 430 & 30 & 3350 \\
\hline 90 & - & 30 & 1800 \\
\hline \multirow[t]{2}{*}{ Not added } & - & 30 & - \\
\hline & & \multicolumn{2}{|c|}{ Period of incubation } \\
\hline $\begin{array}{l}\text { Bovine albumin } \\
\text { added at } \\
\text { (hr.) after } \\
\text { inoculation }\end{array}$ & $\begin{array}{c}\text { Cells } \\
\left(10^{8} / \mathrm{ml} .\right)\end{array}$ & \multicolumn{2}{|c|}{$\begin{array}{l}4 \mathrm{hr} \text {. } \\
\text { Coagulase formed } \\
\text { (M.c.D. } / \mathrm{ml} \text {.) }\end{array}$} \\
\hline 0 & $11 \cdot 9$ & 1760 & 5000 \\
\hline 1 & $12 \cdot 3$ & 900 & 3750 \\
\hline 2 & 17.9 & 700 & 3800 \\
\hline 3 & $84 \cdot 0$ & 275 & 3000 \\
\hline 4 & - & 275 & 750 \\
\hline Not added & - & 275 & 750 \\
\hline
\end{tabular}

\section{DISCUSSION}

Davies (1951), who first studied in detail the action of serum on the production of free coagulase, considered two possibilities: $(a)$ that a pro-coagulase is formed in large amounts on the cell surface during the lag phase and is subsequently shed into the medium, in small amounts without serum and in large amounts in its presence; $(b)$ that the cells form a pro-coagulase during the lag phase, serum accelerates this formation and when cell division starts pro-coagulase is no longer formed. Davies applied the term 'pro-coagulase' to the material liberated into broth and which, in his terminology, combines with coagulase activator to give coagulase. His 'pro-coagulase' is thus identical with the coagulase of all other authors and his coagulase with the so-called 'coagulase thrombin' of Miale (1949). It is therefore unnecessary to introduce other and more confusing terms.

The present studies, while confirming the importance of serum or, as it now appears, of albumin in the formation of coagulase, do not support some of the conclusions drawn by Davies, nor are the facts covered by the possibilities he put forward. The free coagulase which Davies studied is formed early in the growth cycle and is liberated continuously both in the lag and logarithmic phases. Since no evidence could be obtained in the present studies for the liberation of measurable amounts of free coagulase by lysed or crushed cells grown without albumin, it seems unlikely that the role of albumin is that of a liberator of preformed coagulase. The evidence points to albumin as being directly concerned in coagulase formation or as exercising a protective action 
on coagulase by preventing its destruction by proteolytic enzymes or surface denaturation. There is at present no evidence in favour of this latter possibility. Lominski, Smith \& Morrison (1953) showed that a coagulase-destroying enzyme (possibly a protease) occurred in cultures of weakly coagulase-positive variants or in coagulase-negative strains of staphylococci. Such an enzyme, if present during coagulase production, might cause considerable loss and its inhibition by albumin would explain the enhanced production in the presence of this substance. Unfortunately for this explanation the coagulase-destroying enzyme, like most if not all bacterial proteases (Duthie \& Lorenz, 1949) was inhibited by serum globulin and by egg albumin (neither of which affect coagulase production) while serum albumin failed to inhibit it (Lominski, personal communication). Experiments made with purified coagulase in broth showed that while it was readily denatured by shaking in the presence of air, no protection was given by albumin. For these reasons it is thought that the function of albumin is not a protective one.

Strains giving good yields of coagulase in the absence of albumin are rare, and it has so far been impossible to obtain partially purified coagulase type $\mathbf{D}$ in a form suitable for the production of antisera. The addition of cadmium sulphate to coagulase grown in an albumin containing medium, gave a precipitate which contained large amounts of albumin. No satisfactory methods for separating the albumin from the coagulase could be discovered and further purification was abandoned.

I wish to thank Mr H. Proom of the Wellcome Research Laboratories and Mr J. C. Francis for many of the staphylococcal strains used. I am very grateful to Dr H. J. Rogers for very helpful discussions and to Miss S. Isherwood and Miss J. Rowlands for valuable technical help. The work was carried out under a research grant from the South-West Metropolitan Regional Hospital Board.

\section{REFERENCES}

Biggs, R. \& Macfarlane, R. G. (1953). Human Blood Coagulation and its Disorders. Oxford: Blackwell Scientific Publications.

Davies, G. E. (1951). Factors influencing the in vitro production of staphylococcal coagulase. J. gen. Microbiol. 5, 687 .

Duthie, E. S. (1952). Variation in the antigenic composition of staphylococcal coagulase. J. gen. Microbiol. 7, 320.

DuthiE, E. S. (1954). Evidence for two forms of staphylococcal coagulase. J. gen. Microbiol. 10, 427.

Duthie, E. S. \& Lorenz, L. (1949). Protease inhibitors. 2. Bacterial proteases and their inhibitors. Biochem. J. 44, 173.

Duthie, E. S. \& Lorenz, L. (1952). Staphylococcal coagulase; mode of action and antigenicity. J. gen. Microbiol. 6, 95.

Lominski, I. (1944). Preparations of cell-free plasma coagulase of Staphylococcus aureus. Nature, Lond. 154, 640.

Lominski, I., Smith, D. D. \& Morrison, R. B. (1953). A coagulase-destroying factor produced by variants of Staphylococcus aureus. Nature, Lond. 171, 214.

Mrale, J. B. (1949). The role of staphylocoagulase in blood coagulation. I. The reaction of staphylocoagulase with coagulase globulin (CG) to form coagulase thrombin (CT). Blood, 4, 1039. 
TAger, M. \& Hales, H. B. (1947). Qualitative coagulase and toxin production by staphylococci in relation to the clinical source of the organisms. Yale J. Biol. Med. 20, 41 .

Walker, B. S., Derow, M. A. \& Schaffer, N. K. (1948). The partial purification of staphylocoagulase and the effects of certain presumptive inhibitors upon its plasma-coagulating action. J. Bact. 56, 191.

Walston, H. D. (1935). The clotting of plasma through staphylococci and their products. J. Hyg., Camb. 35, 549.

(Received 13 November 1953) 